Global Conferences Series:

Social Sciences, Education and Humanities (GCSSSEH), Volume 3, 2019

The $1^{\text {st }}$ International Conference on Education, Social Sciences and Humanities

DOI: https://doi.org/10.326/hum0195

\title{
Why Vocational School Students Drop Out: Uncovering the Relation between Rural Business Development and Teenagers' Interest in School in Blitar East Java
}

\author{
Agung Winarno ${ }^{1}$ Siti Robfi'ah² Madziatul Churiyah $^{3}$ \\ 1,2,3 Universitas Negeri Malang \\ agung.winarno.fe@um.ac.id
}

\begin{abstract}
This study aims to reveal the reasons for Vocational High Schools students, Department of Marketing, in south Blitar to choose working rather than completing their school. Besides, it is intended to uncover the benefits of marketing expertise for the profession of being a salesperson, and to study the impact of the decision. It employs a phenomenological qualitative approach. The subjects are students who chose to drop out of school. Data analysis is carried out using the following stages: Doing Approach, Collecting Data, In-depth learning, Matching, Making Interpretation and Presentation. The result shows that the students choose to work rather than to complete their school due to the growing business around their environment, family, and surrounding society, as well as the learning experiences at school. The marketing expertise they gain successfully leads them to be a well-prepared salesperson, that they tend to choose to work immediately instead of waiting until they graduate
\end{abstract}

Keywords: Dropout Vocational School Students, Marketing Expertise, Rural Business Development

\section{Introduction}

Vocational high school (SMK) students are teenagers, and they are in the age of inner turmoil to find their true identity. Adolescence is, according to Steinmetz (2002), a unique period referring to childhood and adulthood, based on the period of "stress and storm" or "awkward age", a chaotic and confusing period. Adolescence can be classified into two stages: the beginning (age 13-16 years) and the end of puberty (age 16-18 years), or according to Santrock (2009), it is between 18-21 years old.

Students who study at vocational school are generally in the phase of middle adolescent, 15-18 years old. In this phase, the urge to live independently from family comes up, but a friend who can understand and help them out is highly needed. They start looking for reliable role models to honor and to figure out.

Copyright (C) 2019, the Authors. Published by Redwhite Press.

Page | 53

This is an open access article under the CC BY-NC license

(http://creativecommons.org/licenses/by-nc/4.0). 
The search for the model initiates them to determine life vision, including the perception over the importance of learning at school.

Regardless of age, adolescents are always associated with the golden age for study. It is in line with the Republic of Indonesia Minister of Education and Culture Regulation No. 19 of 2016 concerning Program Indonesia Pintar (Smart Indonesia Program) which states that PIP is intended to increase the access for children aged 6 to 21 years to get education services until high school to support the 12-year compulsory education program. However, many school-age children are found to drop out of school due to various factors.

Oktaviani(2012) found that junior high school graduates do not pursue their education due to some reasons: 1) experiencing trauma during schools, such as finding punishment or unpleasant teachers, 2) making friends with somebody who does not study at school, that they perceive school unimportant, and 3) less motivation from the parents related to the importance of school. Slightly different from Oktaviani, Winarno (2017) found that many adolescents are reluctant to pursue their studies after primary education. They drop out of school at the vocational school level due to the rural business development, the discovery of rich sources around them, and the fact that they are far from a formal school. They feel better working because they can earn money. Moreover, their parents prefer their children to work that the family's economy is supported.

Another factor is that the willingness to help parents for the family economy. Also, some of them find one of their parents passed away so that they take over the role of the family head. Nastalia (2007) found that one of the reasons why teenagers work even migrate is family support, parenting, family problems, and the loss of parents. It can also be due to the ineffective role of the teacher in guiding the students, especially those in Vocational school (Houtte, 2016). Besides, friendship also influences them to drop out (Ricard, 2016).

The current research is conducted to reveal more factors and impacts behind the decision of Vocational School students to choose to work rather than to finish their school. Furthermore, it aims to find out the benefits of this Department for the profession of a salesperson.

\section{Method}

This study employs a phenomenological qualitative approach to show the students' reasons to decide to work rather than to complete their school. The main informants of the current study are 15-18-year old students who drop out of SMK in Kademangan, South Blitar, from 2017 to 2018, and are actively working in the formal sector (sales staff). In addition to the students, the researcher also involves parents to be an informant. The data are explored using an in-depth interview, observation, and documentation. Triangulation over the sources and methods is done to find accurate information. The analysts is conducted with simultaneous stages of 6 (six) activities: Doing Approach, Collecting Data, In-depth learning, Matching, Making Interpretation and Presentation.

\section{Results and Discussion}

\section{The Reason for Choosing to Work}

The study shows that students who choose to work rather than to complete their school are driven by several factors: 1) personal will to learn to live independently and to make income themselves; 2) the environment in which some teenagers of the same age or even under their age have already been working, 3). The far distance to go to school; 4) the availability of job opportunity near their home, and 4) 
the uncomfortable learning experience at school. The essential factor in the availability of job opportunity around as an indicator of rural economic growth.

The current finding has primarily been explained in the study of Winarno (2017) on teenagers who drop out of school and who do not pursue the study to the higher school. It shows that the main factor is family support, economic condition, and rural businesses development which causes the increase of job vacancies as a salesperson, and mining businesses, as well as the far distance between formal schools and their homes. Moreover, the number of teenagers of their age who is directly working is also the driving factor for their dropping out of school.

Sulistyawati et al. (2016) who study on dropped-out junior high school students also found that personal internal condition has a significant influence on the students' decision to continue their school or not. The decision to work due to self-willingness refers to personal factors. Her finding also explains the environmental factors that influence students' decisions to work directly. The research of Rahmat (2014) related to career choices finds that the decision on their career is influenced by environmental conditions comprising the number of job opportunities and values driven by their parents. Also, students assume that working can help the economy of the family and ease the burden of parents towards their families. The finding is in line with that of Wijianto \& Ulfa (2016) which shows that there is significant influence between an economic condition and the motivation of early adolescent to work. Besides, Tsaneva (2017) explains that the financial conditions of the family also influence drop out, and scholarship might sometimes become the solution.

What is interesting from the current study is that the internship practices of the students in the Department of Marketing may provide real learning experience such as the description over something to do by a salesperson. Exposure during internship may increase their' confidence to work as salesperson or to apply for the opportunities near their house. This factor has already been found in the previous research that the experience along the 8th grade during internship, productive training and family support could affect students' confidence to work. The ability to do the tasks and to face problems during an internship can drive teenagers to feel that they have enough skills to apply for the job vacancies (Lestari \& Siswanto, 2014; Baiti \& Munadi, 2014)

The experience of an internship can increase the students' confidence when they work one day, but it also causes a negative impact on students. Doing an internship with permanent employees (workers in the industrial workplace) with the lower educational background can influence the students' perspective. Informant 2 and 3 reveal that even though they do not have a high school or vocational level education background, they still could work as a salesperson. They might perceive that even if they do not graduate from vocational school, they can still find jobs with the same income as others who graduated from vocational high school. The same amount of income leads them to choose to work without completing school. School should improve cooperation with business or industrial company which requires a minimum of high school or vocational education over the recruitment process. Therefore, students' perspective on the importance of education can improve.

The Benefit of Marketing Program

The finding shows that students in the marketing program realize that they have enough knowledge and skill needed by a salesperson. It is in line with the learning content at school which has provided some necessary competencies comprising: simulation and digital communications, business economics, general administration, marketing, business plan, business communication, retail business management, online business, product structuring, transaction administration, creative products, and entrepreneurship (Kemendikbud, 2017). After learning from the Marketing Department, students stated that knowledge 
could improve their selling skills, such as operating the system of the teller, giving customer service, arranging goods, and facing customers.

The Decree of the Indonesian Minister of Education and Culture No. 323/U/1997, states "Dual system education, hereinafter referred to PSG, is a form of vocational expertise education that systematically and synchronously integrates education programs in vocational secondary schools with skill mastery obtained through direct practice in the partner company. It is a directed plan to achieve a certain level of professional expertise. The regulation shows the combination of the implementation of learning at schools (SMK) with the implementation of industrial work practices (internship) in an institution (company, service, trade, industry), synchronous and systematic, aiming to deliver students to certain work mastery, so that they become graduates who are relevant as expected. The Marketing Department prepares students for a career in marketing, one of which is a salesperson. The internship also provides a certificate which may help when applying for a job as a salesperson. It can increase the confidence in the workplace because they many things related to sales when studying in marketing through various programs.

The Impact of Choosing to Work

The decisions to work may have a negative influence on the surrounding friends. Some of their friends decide to quit school and start working. This finding is in line with the results of research by Haidar (2016) that the adolescents working in batik Pekalongan show that peers and playmates are very influential upon their behavioral patterns. Thus, it is common when a student chooses not to finish school is imitated by the surrounding adolescents.

Another impact of the student's decision after dropping out of school is anxiety for being underestimated by others because they are only a graduate of junior high school. They might feel inferior to reconnect with their friends who continue their study until they graduate. What makes this finding interesting is the fact that they are discomfort when their peers follow the decision. The fear of the informants that the peers will do the same thing is quite reasonable, considering that they used to stop due to following other friends. They are anxious about being followed by their peers because they find it more difficult after experiencing the work. According to Jahja (2011), this is common because the developmental phase from 15 to 18 years includes in middle adolescents with susceptible characteristics, one of which is the need to friends who understand and help, and figures to share anything happy sad. In this phase, teenagers start looking for something or someone figure out. The search for this model initiates the youth to determine their life perception and dream.

On the other hand, even though they have experienced working, their difficult phase over earning money, they are also proud of their decision to work because they perceive to be able to contribute to the life of their parents. They intend to help their family lives (Wijianto \& Ulfa, 2016). It also shares the same ideas as the findings of Campbell C. (2015) which states that dropping out of school has no any relation to the economic difficulties because many graduates also end up with unsafe economic conditions.

\section{Conclusion}

The research concludes that the factor leading students to choose to work rather than to complete school is the willingness to live more independently, to help the family life, and to grab the broader opportunities to work in the trade sector around their house. Besides, they are confident after going through enough experience during school. Moreover, there is still an assumption that school is not essential for the family and society. The far distance between their house and the formal schools also drives them to drop out because it involves transportation costs that cannot be made by their parents. On 
RedWhitepress Global Conferences Series: Social sciences, Education and Humannities (GCSSSEH), Volume 3, 2019

the other hand, they decide to drop out under the concerns that they will underestimate them in the future because of having a low level of education and feel the difficulty of working to make money. Thus, they do not want their peers to follow the decision.

Managers of educational institutions need to be more selective in choosing the place of internship for the students to avoid the adverse impacts of workers. An effort to make non-formal schools around the area where many children drop out, especially in the villages with growing business around. Additional education is also required. Those who drop out of school still want a higher level of education.

\section{References}

Blitar Central Bureau of Statistics (2015) Workforce Technical Concept or Explanation (online), (https://blitarkab.bps.go.id/).

Baiti, A. A \& Munadi, S. (2014) Influence of Practical Experience, Learning Achievement Basic of Vocational and Parental Support for Work Readiness of Vocational Students. Journal of Vocational Education, 4 (2).164-180. From (https://journal.uny.ac.id/index.php/jpv/article/viewFile/2543/2100).

Campbell, C. (2015) The Socioeconomic Consequences of Dropping: Evidence from an analysis of siblings. Volume 51. Pages 108-118. ISSN 0049-089X.

Decree of the Minister of Education and Culture of Indonesia Number 323 of 1997 concerning Medical Education Double.

Haidar, AF. (2016) Education Aspirations of Youth Working in the Pringlangu Village Batik Industry Pekalongan City. Education Policy Journal 5 (3).279-291. From (http://journal.student.uny.ac.id/ojs/index.php/sakp/article/view/5217).

Houtte, M \& Demanet, J. (2016) Teachers \& students, and the intention of students to drop out of secondary education in Flanders, Teaching and Teacher Education.Volume 54. Pages117-127. ISSN 0742-051X.

Jahja, Y. 2011 Developmental Psychology. Jakarta: Kencana Prenada Media Group.

Law No. 44 of 2006 concerning Citizenship of the Republic of Indonesia Article 4 number 4 (online), (http://m.hukumonline.com/klinik/detail/lt4eec5db1d367/perbosisi-batasan-usia-cakap-hukumdalam-peraturan-perundang-undangan).

Lestari, I \& Siswanto, B. (2015) Effect of Employee Experience, Productive Learning Outcomes and Social Support on Work Readiness of Vocational Students. Vocational Education Journal, 5 (2) .183-194. From (https://journal.uny.ac.id/index.php/jpv/article/view/6384/5517).

Nastalia, F. A. (2007) Perseverance in Overseas Youth Workers. Journal of Psychology , 1 (1), 81-89. ( https://media.neliti.com/media/publications/100198-ID-ketabahan-hati-pada-puruh-remajaperan.pdf).

Oktaviani, A. (2012). Low Case Study of Motivation to Complete Middle School Graduates in Giriwungu Village, Panggang Gunungkidul District. Emphaty Journal, 1 (1), 19-31

Rahmat, D. (2014) Factors Affecting Career Decision Making for Students in the Department of Guidance and Counseling. Journal of Guidance and Counseling , 3 (2).20-24. From (http://journal.unj.ac.id/unj/index.php/insight/article/view/2151).

Republic of Indonesia Minister of Education and Culture Regulation Number 19 of 2016 concerning the Indonesia Smart Program (online), (http://psma.kemdikbud.go.id)

Ricard, N. \& Belletier, L. (2016). Dropping out of high school: The role of parent and teacher selfdetermination support, reciprocal friendships and academic motivation. Volumes 44-45. Pages 3240. ISSN 0361-476X.

Santrock, J. W. (2009) Educational Psychology .Jakarta: Salemba Humanika. 
Steinmetz, S. K. (2002). Adolescence in Contemporary Families. (https://link.springer.com).

Sulistyawati, RA. et.al. (2016) Relationship between Internal Individual Conditions and Accessibility of Grobogan Kradenan Middle School 3 Middle School Students towards the Decision to Continue School.GeoEco Journal, 2 (1). 80-87. From (https://jurnal.uns.aci.id).

Tsaneva, M. (2017). Does school matter? Learning outcomes of Indonesian children after dropping out of school. World Development Perspectives Volume 6. Pages 1-10.ISSN 2452-2929.

Winarno, A (2017) Value Perplexities between Education and Money in East Java, Adolescence in Social Science, Education and Humanities Research (ASSEHR) volume 109 4th Asia Pacific Education Conference (AECON 2017).

Wijianto \& Ulfa, I. F. (2016) Effect of Social Status and Family Economic Condition on Work Motivation for Early Adolescents (Ages 12-16 Years) in Ponorogo Regency. Journal of Al Tijarah, 2 (2). 190-210. 